\title{
THE RELIGIOUS CONNOTATIONS OF THE SOVEREIGN IN DESTITUTION IN THE MALAY HIKAYAT
}

\author{
Noriah Taslim \\ tnoriah@gmail.com
}

The Institute of the Malay World and Civilization, Universiti Kebangsaan Malaysia, 43600 Bangi, Selangor Darul Ehsan, MALAYSIA. Tel.:+ 603-89213696.

\begin{abstract}
The essay is an attempt to highlight the significance and the extent of religious influence on classical Malay literature. It plans to do this through the analysis of the structural elements of the plot at both at the surface and underlying level. To narrow down the analysis, only one genre of Malay literature, the so-called hikayat romance will be taken as corpus of investigation. To allow room for a more comprehensive analysis within this restricted corpus, two types of hikayat romance will be taken to task; these are the fantasy/court romance and the hagiographical romance. Both of these works are suitable for this study as they exhibit a remarkable level of religious influence in their textual elements. The analysis, however, will focus especially on the "exile motif" which is the controlling and generative element in the plot.
\end{abstract}

Keywords: hikayat romance, generic structure, exile motif, Hindu interpretative model, sufistic interpretative model

\section{HIKAYAT AS A GENRE FORM IN MALAY LITERATURE}

Within the genre structure of Malay literature viz. the medieval (15th-16th century) and the classical period (17-19th century), hikayat (as well as syair and kitab), in its general sense, denotes the genre form rather than genre per se (see Braginsky, 2004). As a genre form, hikayat designates works of 
diverse content and applies to some historical writings, certain hagiographic works, edifying mirrors (hidayah) and almost all court/fantasy romances. Nevertheless, in Malay literature, the term hikayat itself refers literally and exclusively to prose and semi-prose works of fiction or semi fiction (the Malay equivalent being cerita).

The hikayat, like many other Arab/Persian cultural manifestations in the post-Islamic period, was introduced with the coming of Islam. The first experience of the Malays with the hikayat was most probably was in the form of two Arab-Persian epics-the Hikayat Amir Hamzah and Hikayat Muhammad Hanafiyyah; both were very warmly received in the MalayIslamic world. At first, the term hikayat was applied to all written prose/ semi prose oral stories, especially the court romance (in their oral rendition, these texts are called cerita). Over time, hikayat evolved into one of the most popular genre forms adopted by Malay writers, and was loosely used to indicate various genres of Malay traditional literature. As a matter of fact, the term hikayat was even applied by more recent, modern authors to memoirs such as Hikayat Abdullah, and creative works such as the early Malay novel Hikayat Faridah Hanum.

In this essay, to avoid confusion, I therefore categorize hikayat into two: one is the hikayat proper (the hikayat of classical literature) which I call the "hikayat romance" (the fantasy/court romance), while the other category includes all other genres using hikayat as a form of genre.

Historically, the hikayat romance made its first appearance against the background of the transitional period from Hinduism to Islam (the medieval period). In literature, this period was characterized mainly by the "Islamization" of pre-Islamic (Hindu/animistic) texts, the result of which was a highly synthesized Malay literature, breeding hybridized forms of texts and genres, one of which was the synthesized hikayat, being one of two good examples of synthesized genres, the other being the annals, or silsilah literature (for details read Noriah, 2007).

These synthesized genres, more so the hikayat, became significant literary forms in traditional Malay literature. However, in the later period of Islam (the classical period), one may note that the synthesized character of the hikayat became less apparent. Under the stronger influence of Islam, like most writings of the post-Islamic period, the genre became more aligned to Islam and its contents showed a greater affinity with Islamic ideas, themes and motifs. Consequently, it became more rigid where content is concerned. In this paper, however, both types of the hikayat will be analysed. 


\section{THE GENERIC STRUCTURE OF THE HIKAYAT}

The structure of the hikayat, whether highly synthesized or otherwise, despite the unusual diversity of motifs, is basically rather simple, stable and uniform. The text begins with the birth of a prince in a prosperous kingdom. Then follows an account of his misfortune or deficiency-"villainy" and "lack" in Proppian morphology (Propp, 1968) which forces the young hero to leave home. Next comes the story of his long wanderings, the obtaining of magical tools from donors or help from helpers; his battles with his adversaries; liquidation of lack or villainy; marriage, and his ascension to the throne.

The hikayat is also distinguished by various structural features quite peculiar to its kind. One fundamental element of the plot is the "exile motif" which occurs prominently in almost every text, in various guises. In Hikayat Ibrahim ibn Adham, ${ }^{1}$ the "exile" is takes the form of the act of membuang diri (to exile oneself); another example of the motif of exile as is found in Hikayat Malim Deman, where it manifests as going on a journey; while in Hikayat Awang Sulung Merah Muda, the sovereign is dinyahkan (banished).

The causes for the exile are various, ranging from evil prophecies of a fortune teller, the actions of a jealous step-mother or minister, or even a garuda (mythical giant bird) attack. For instance, in Syair Selindang Delima, the exile results from the attack of a giant garuda who wipes out the whole kingdom, with the exception of Raja Abang and his sister, Seri Benian, who survive because they hide in a huge cauldron. Raja Abang then invites his sister: "Come on, let us go into exile, let us go into the virgin forest, perhaps we might find an inhabited spot, where someone might take us under his protection" (Bausani, 1978:47)

Whatever the case may be, the exile motif is inherent in the plot schema of the hikayat romance. In every situation, a certain court disaster will befall the kingdom which then creates a situation where the king, prince or princess is forced to leave and live far from the kingdom, usually as a fakir (beggar, vagabond), a commoner such as a peasant, fisherman or sailor, and the like, and in all these guises, he or she will always experience destitution and deprivation. The exiled character is lost in the jungle, robbed and has to beg for food and shelter; he or she may also be kidnapped and kept in a cave or palace as a servant or reluctant bride; or may even be swallowed by a crocodile or ikan nun (legendary whale) or the like.

The reasons for the exile are not always clear. According to the logic of Propp's morphological schema (1968), where each act has to follow another 
on a diachronic plane, the act of exile is a necessary function before the "hero leaves home". And as functions always occur in sequential order, so the "exile motif" fills the appropriate slot in the tale schema.

But a more rewarding and enriching interpretation is given by Bausani (1978). In his "Theory of Myth", the exile motif is given a transcendental interpretation, which links this leitmotif to the Hindu myth of the avatara (reincarnation of the Hindu gods). Based on this transcendental interpretative schema, I will try to analyse texts of the hikayat romance genre. Nevertheless, this interpretative framework is not conclusive to all hikayat romance; it is found to be compatible especially with hikayat that have very strong Hindu influences, such as Hikayat Si Miskin, Hikayat Seri Rama, Hikayat Dandan Setia and so forth.

On the other hand, there are also hikayat of this genre which show strong Islamic overtones, such as the Hikayat Syah Mardan and the Hikayat Sultan Ibrahim ibn Adham. In these texts, the exile motif is still very prominent in the initial plot; but various textual features caution me from using the same interpretative schema. Based on my understanding of the "mystical quest" of the Muslim sufis and its popular rendition and depiction in various literary forms, I will instead attempt to explain this phenomenon by reading it within the spiritual dimension of the Islamic or, specifically, the sufistic framework.

\section{BAUSANI'S INTERPRETATIVE MODEL}

Bausani's theory of myth derives its logic from the prototype structure of Hikayat Sang Samba, a Malay/Javanese rendition of the Mahabharata. An early episode from the text will help illuminate our understanding of the theory. I will reproduce here the text from Bausani (1978:48):

Once the great God Wisynu was seated on his throne to hold an audience in the celestial realm. In his heart he thought 'it is good that I should descend into the world to join the Pandawas so that my name may become famous in the world'. Having thought this he descended on Mount Tenuman. In the mean time, Darma Dewa, was holding his wife asleep in his lap. Wisynu told him: 'My son Darma Dewa, come with me and let us go to incarnate ourselves in the spouse of King Pasu Dewa'. Darma Dewa replied: 'Very well, I shall join Your Majesty immediately'.

After having spoken thus Wisynu incarnated himself in the wife of Maharaja Pasu Dewa... When Wisynu had incarnated himself in his wife, she gave birth to another son who was exceedingly handsome.... His father called him Betara Kesna ... 
One day Darma Dewa ... remembered the promise which he had given Wisynu, and because of his great love for his wife he cried bitterly ... saying, "If a son will be born to Betara Kesna called Sang Samba it will be me!" ...

Then, having shed all compassion, he descended ... to incarnate himself in the spouse of Batara Kesna, who was called Dewi Jambuwati.

Based on this episode, Bausani (1978:49) concludes his findings:

The exile and departure of the sovereign of the great capital city of hikayat is the euhemerisation of the descent from a level of the Hindu avatara. The variants are numerous, but the substance remains the same: in the realm of the "keinderaan" a disruption happens which is nothing else but the loss of level.

It is difficult to deny the typological affinity of this transcendental schema with all the other stories in the hikayat romance. Under the influence of the Hindu-Buddhist concept of the chain of rebirths, the structural pattern of these hikayat was reinterpreted as an account of the descent of a divine or semi-divine hero, of his incarnation, life and exploits. A typical compositional structure of a hikayat can then be divided into two parts: the first part presenting an account of the hero's life in his first stage of incarnation (different levels of human existence), and the second narrating events in the second stage of incarnation or the return to his origin/kingdom of archetype. The two parts constitute the three elements of the plot: exile, journey and return.

This mythic structure is embedded in Hikayat Seri Rama, Hikayat Marakarmah, Hikayat Langlang Buana and others. For instance the misfortunes of Maharaja Indera (Si Miskin) in Hikayat Marakarmah, once a celestial being, begin after he is cursed by Indra and has to be born on earth. The protagonist of Hikayat Parang Puting is born to the daughter of a celestial king who was slandered and banished to earth; Indra Bumaya, the protagonist of Hikayat Langlang Buana, was in his previous incarnation a king of celestial beings; the protagonist of Hikayat Dandan Setia was a princess in a celestial kingdom but was cursed and banished to earth (incarnate in the wife of a king) for causing war among her suitors.

After investigating several hikayat romances, I found that the structural pattern which constitutes the different levels of existence of the avatara is inherent in the plot of the narratives. However, due to lack of space, I will instead take only one hikayat as the most representative example of the analysis. Below is the interpretative framework based on the transcendental analysis of the exile motif in the plot of Hikayat Si Miskin (Hikayat Marakarmah): The 
structure will be shown in a cyclical movement which denotes the different levels of existence, that is, the descending level of the avatara (process of humanization/degradation) and the ascending level of the avatara (process of dehumanization/returning to original level/state).

\section{The Plot Structure of Hikayat Si Miskin (Hikayat Marakarmah)}

(1) Initial situation: (the celestial level): Marakarmah was born to a great king in a prosperous kingdom.

(2) Disaster at court: evil prophecy of soothsayer: Marakarmah is said to bring bad luck to the kingdom.

(3) Exile: Marakarmah and his younger sister are banished by his father to the forest:

Proses of destitution/degradation:

(a) He has to starve and beg for food.

(b) Caught as thief, beaten, tied up and thrown into the sea.

(c) Separated from his sister.

(d) Rescued by a princess (held captive by man-eating ogre), marries the princess.

(e) Both saved by the captain of a ship.

(f) Marakarmah works as a member of the ship crew remains anonymous.

(4) Lowest level of degradation/death:

a) Marakarmah is thrown into the sea by the ship captain who fancies Marakarmah's wife.

b) He is swallowed by a fish (ikan nun).

(5) Rebirth/recognition:

(a) Marakarmah is brought back to life and nursed back to health by a nenek kebayan (witch) who has found him in the belly of the fish.

b) He is reunited with his wife and sister.

c) Reunited with his parents.

d) Recognized as their son (the hero is recognized).

(e) Ascends the throne and becomes king. 
(6) The celestial state/level.

The king is reinstated - the cycle is completed.

Thus, by using the Hindu myth as the interpretative paradigm, the exile motif and all the other plot elements could be explained more rationally. The analysis, besides other things, also brings to light the dynamics behind the structuring of the plot in the hikayat. Despite their seemingly secular appearance, these hikayat are, in essence, an enactment of the sacred myth of the Hindu avatara; his descent and ascent in the cycle of rebirths gives these texts their typological structure. The so-called archetypal schema is prevalent in most of the hikayat romances, especially those of the highly synthesized genres.

The plot schema of Hikayat Marakarmah, may be represented diagrammatically as below (Figure I):

The celestial state
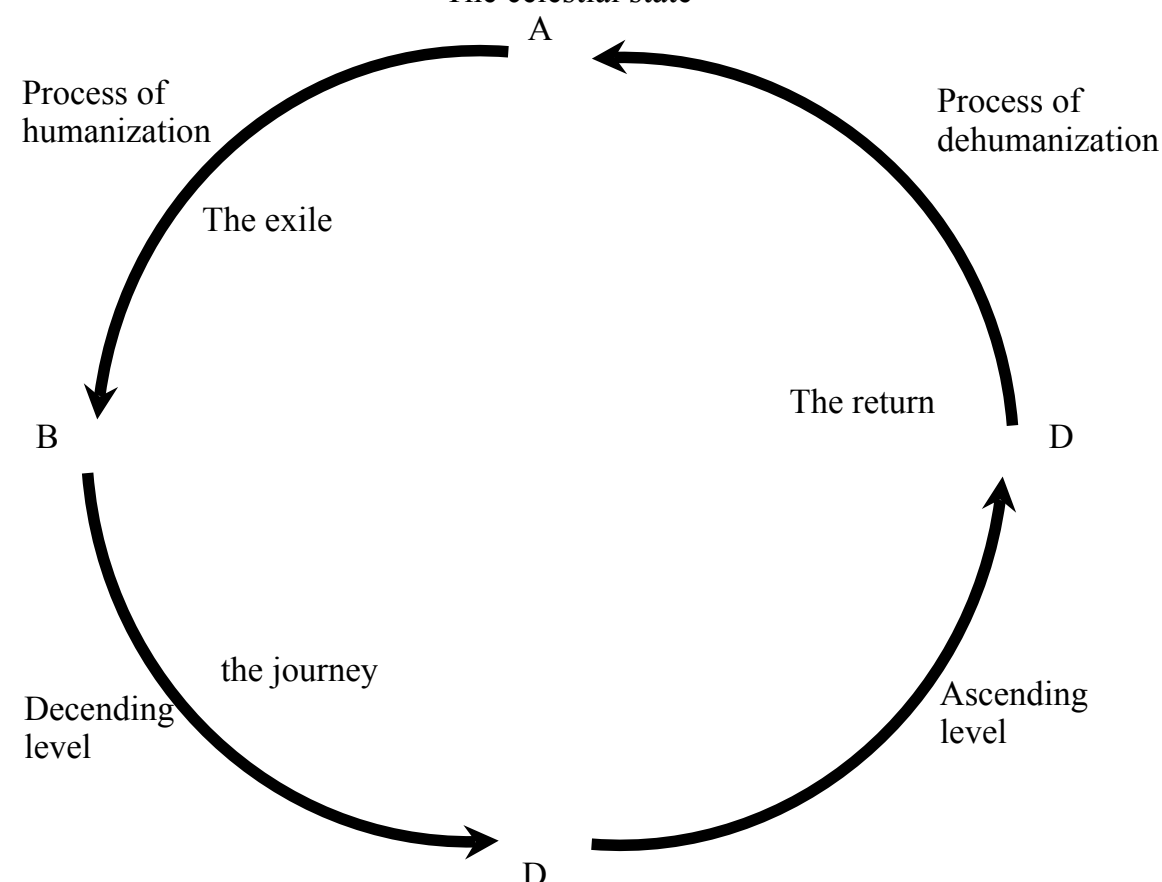

The destitution state

Figure 1 The descending and ascending levels of the avatara. 
A - C: The descending level of the avatara/ the process of humanization/ degradation

C - A: The ascending level of the avatara/ the process of dehumanization

\section{THE SUFISTIC INTERPRETATIVE MODEL}

Bausani's interpretative schema, as mentioned earlier, is however only applicable to the highly synthesized hikayat, i.e. those characterized by strong Hindu/Buddhist influence, although the schema may also be visible in the later Islamic hikayat; the Hikayat Maharaja Ali is a good example of an Islamic hikayat that contains this underlying structure in its plot, (see Bausani, 1978 and Noriah, 1993). However, for a the less common stock of hikayat, such as hagiographic romances and sufi allegorical romances, we may need to be more cautious. The mythic interpretative schema may not suffice to explain the structural features of these hikayat which are more Islamic in nature.

These appear to be quite a different category of hikayat. The hagiographic romance generally relates the life journey of saints and devout princes/kings, while the allegorical romance is an account of the physical and or spiritual journey of the Muslim ascetics, the sufis/gnostics (the so-called "seekers"), depicted through the use of symbolic and metaphoric expressions which mostly are highly esoteric in nature. While the journey in the former may be literally interpreted, its structural elements, similar to those in the latter, are embedded in the mystical complex of the sufi doctrines and beliefs, and thus steeped in sufistic connotations and have to be read as such.

Moreover, both these kinds of hikayat share the same compositional structures of the ordinary hikayat romance (discussed earlier), as well as the component units of its plot, i.e. exile, journey and return. However, as we shall see later, they do not exhibit the underlying typological structure of the earlier hikayat romances. Yet, we are often struck by the close affinity of the textual structure of all these hikayat. The similarity in most cases could probably be explained as an outcome of the genre convention, while in some other cases, the structure appears to be a literary device used by the author to express in allegorical form certain abstract ideas, or subtle experiences which resist direct expression or description.

The latter can, for example, be seen in the second type of hikayat (the allegorical romance) which employs the typical structure of the romance 
wholesale, and as such may be read as one. Someone more enlightened, however, would probably read it more cautiously and emphatically so as to be aware of the mystical connotations and the esoteric nature of the structural elements of the plot and the symbols in the narrative. One allegorical reading of such a hikayat is done by Braginsky (1990; 1994). Through a highly esoteric interpretation (takwil) of Hikayat Inderaputera and Hikayat Shah Mardan, he has shown that both texts were not mere romances in the general sense but mystical or, more specifically, sufi texts which function as a transcendental media, an ascension ( $m i^{\prime} r a j$ ) for the gnostics to achieve "oneness" or spiritual unity with God.

In the Malay Islamic world, literature - poetry and prose --was always chosen as medium of expressions for sufism (as well as other mystical practices) not only for its doctrines but also to express the spiritual experiences of its followers. The texts normally describe the mystical quest, the stages (maqam) of ascent (normally divided into three levels of human souls - the evil soul, the critical soul and the perfect soul); the obstacles faced by the human soul in its "vertical" journey (tariqah) to embrace the Divine Presence (fana).

While all Muslims believe that they are on the pathway to God, sufis believe that it is possible to draw closer to God and fully embraced the Divine Presence in this life. And this may be achieved through rigorous purification of the lower self (nafs ammarah) through such actions as repentance, the purging of contemptible qualities, the stripping of worldly desires (zuhud), the total submission to God and living in perpetual remembrance of Him (zikr), of fear (khawf) and love (asy') for Him.

It is however, not possible to spell out in length the sufi doctrines and practices in this essay; the quotation below taken from Nicholson (1980:59) will hopefully help to summarize the essence of sufism that I have been talking about:

The whole sufism rests on the belief that when the individual self is lost, the Universal self is found, or in religious language that ecstasy affords the only means by which the soul can directly communicate and become united with God. Asceticism, purification, love, gnosis, developed from this cardinal principle.

Therefore, themes of love, quest, journey, adventure/exploits - the stereotypical themes of romance-permeate sufi literature. The compositional structure of these hikayat most often is also similar to the fantastic romance but, as cautioned earlier, has to be interpreted in a different transcendental 
dimension. To illustrate my point, I shall now select and focus on one hagiographic romance, the Hikayat Sultan Ibrahim ibn Adham and subsequently attempt to analyse its structural elements in tandem with the sufi paradigm. The story of this hikayat focuses on the ascetic life of the protagonist, Sultan Ibrahim ibn Adham, his repudiation of kingly and family life, his self-exile, his spiritual journey and wandering. The plot depicts this journey beginning with his self-exile, followed by his quest, the various stages of his adventure, ending with his pilgrimage in Mecca (symbolizing his attainment of the state of fana).

\section{The Plot Structure of Hikayat Sultan Ibrahim Ibn Adham}

(1) The initial situation: Ibrahim Ibn Adham lives as a celebrated king in a prosperous kingdom in Iraq.

(2) Self-recognition: an old dervish teaches him about the impermanence of life and worldly attainment, and that only God Almighty will not be destroyed and will not disappear.

(3) Repentance: The sultan repents and abdicates.

(4) Self-exile: He leaves the kingdom and withdraws into seclusion.

(5) The journey - purification of the soul:

(a) Stage of the zuhud or self-depravation and destitution - the sultan leaves all his worldly possessions, assumes the life of a dervish and spends his life in devotion to God.

(b) The trials - In his journey, two events distract him from the goal of his quest:

(i) while on the journey, he meets a beautiful woman, Saleha (the owner of the fruit that he mistakenly eats) and marries her. much.

ii) they later have a son named Tahir whom he loves very

c) The renunciation of family life: he realizes that his affections for his family distracts him from his mission, regrets, and leaves his wife and son to continue his journey.

d) After a long wandering, his journey brings him to Mecca and he decides to spend the rest of his life there, to be in close proximity with God.

e) His son finally finds him in Mecca and begs him to return to his 
mother, but he ignores his son, instead regarding him as distraction and sending him away.

(6) The attainment of perfection His presence in Mecca, symbolically "the House of God" denotes the final ascent of his journey; symbolically, it is the attainment of the spiritual unity with God or the return to the primordial self.

In this model of analysis, the exile is but a part of the ascetic's journey to purify his soul and achieve perfection, in preparation for the final ascent i.e. the attainment of spiritual bliss. The journey itself is seen as a path to be followed by the ascetic in his ascent to embrace the primordial self or the archetype. Both the exile and the journey can therefore only be interpreted within this sufistic dimension. Similarly, the other elements in the plot such as the quest and the return have to be interpreted within this schema.

The plot schema of Hikayat Sultan Ibrahim ibn Adham may thus be represented diagrammatically as below (Figure 2):

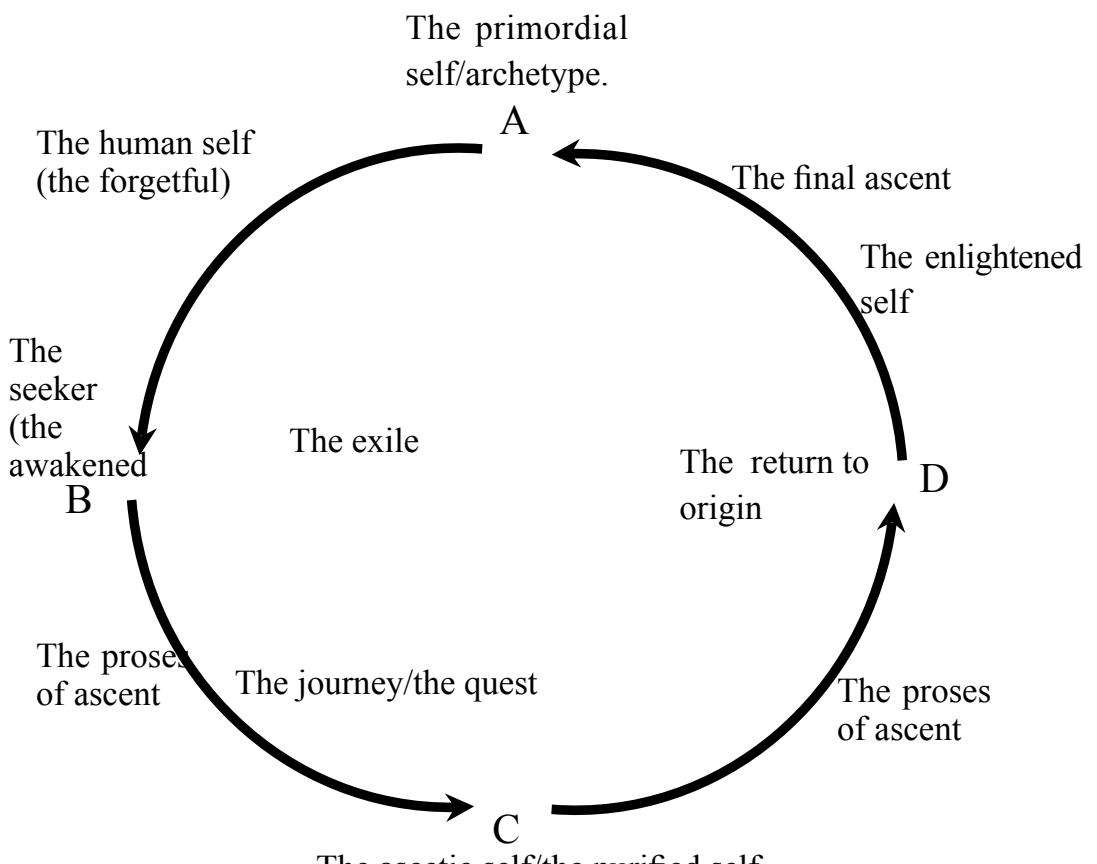

The ascetic self/the purified self

Figure 2 The stages in the journey of the sufi ascetic. 
A-B: the forgetful self - self that succumbs to the lower $n a f_{s} /$ the evil soul

B-C: the awakened self - self that repents/critical soul

C-D: the purified self - zuhud

D-A: the enlightened self - the perfect self

\section{CONCLUSION}

Through the analysis of the two hikayat, the essay illustrates the interconnectedness between literature and religion. Indeed, in Malay society, both in the Islamic and pre -Islamic period, literature could be both sacred and secular at the same time. As the preceding analysis shows, the structure of Malay literature itself was very much influenced by the layers of different religions that came in contact with it. In Malay society, these religions were Hinduism and/or Buddhism, and Islam. The influence of the various religions on Malay literature manifests itself either externally, appearing on the surface structure of the texts, or internally, permeating the underlying structure of the text, embedded in the inner structure of the plot. Such is the case with most hikayat romances, especially those with strong Hindu-Buddhist influence. In many instances, the text itself is used as a medium to depict the spiritual ascension of the self, as found in the practices of the sufis. Here, the plot structure, the exile, the journey and the return have to be interpreted within the sufistic worldview and doctrines. Only then can each element of plot be made more meaningful.

\section{NOTE}

1. Marriage should be seen as a part of the "spiritual journey" of a sufi. It is included in the journey merely to test the spiritual strength of a sufi during the process of distancing or cleansing himself from physical desires. In this journey, women are seen as obstacles to achieving a purer "love", which is the eternal love of God.

\section{REFERENCES}

Abdul Hadi W.M., 2001. Tasawuf yang Tertindas: Kajian Hermeuneutik Karyakarya Hamzah Fansuri. Jakarta: Penerbit Paramadina.

Braginsky V.I., "Hikayat Syah Mardan as a Sufi Allegory" in Archipel 40, pp. 
107-35, 1990.

Braginsky V.I., 1993. The System of Classical Malay Literature. Leiden: KITLV Press.

Braginsky V.I., 1993a. Tasawuf dan Sastera Melayu: Kajian Teks-teks. Jakarta: RUL.

Braginsky V.I., 1995. Erti Keindahan dan Keindahan Erti. Kuala Lumpur: Dewan Bahasa dan Pustaka.

Braginsky, V.I., 2004. The Heritage of Traditional Malay Literature: A Historical Survey of Genres, Writings and Literary Views. Leiden: KITLV Press.

Bausani, A., 1978. "Notes on the Structure of the Classical Malay Hikayat". Translated by Lode Brakel. Department of Indonesian and Malay languages, Monash University, Clayton, Vic (occasional paper).

Abu Bakar Hamid (ed.), 1985. Hikayat Si Miskin (Marakarmah). Petaling Jaya: Fajar Bakti.

Jones, Russel (ed.), 1985. Hikayat Sultan Ibrahim Ibn Adham. An Edition of an Anonymous Malay Text With Translation and Notes. Berkeley: Center for South and Southeastern Studies, University of California.

Nicholson, Reynold A., 1980. Studies in Islamic Mysticism. Cambridge: Cambridge University Press.

Noriah Taslim, 1993. Teori dan Kritikan Sastera Melayu Tradisional. Kuala Lumpur: Dewan Bahasa dan Pustaka.

Noriah Taslim, 1993. "Teori Mitos Bausani dan Struktur Tipologi Sebuah Hikayat" in Noriah Taslim (ed.) Teori dan Kritikan Sastera Melayu Tradisional. Kuala Lumpur: Dewan Bahasa dan Pustaka.

Noriah Taslim, 2007. Dunia Sahibul Hikayat. Kuala Lumpur: Dewan Bahasa dan Pustaka.

Propp. V., 1968. The Morphology of Folktales. Austin: University of Texas Press. Seyyed Hossein Nasr, 1981. Islamic Art and Spirituality. Cambridge: Golgonoza Press. 